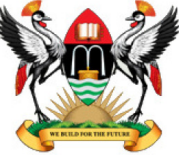

East African School of

Higher Education Studies \& Development
Makerere Journal of Higher Education

ISSN: 1816-6822; 3(1) (2011) 117 - 129

DOI: http://dx.doi.org/10.4314/majohe.v3i1.10

(C) The Author(s) 2011

Reprints \& permission: EASHESD

http://ajol.info/majohe

\title{
The Case Method and Students' Performance at Makerere University Business School
}

\author{
Andrew Musiime ${ }^{1}$ \\ ${ }^{1}$ Makerere University Business School [E-mail: amusiime@mubs.ac.ug]
}

\begin{abstract}
The purpose of this study was to examine the relationship between the case method of teaching and students' performance in a university setting. The study describes the nature of student involvement and engagement in the process of study, especially as stimulated by the use of the case method. The findings indicate a positive relationship between application of the method and students' performance. It is noted that using the method promotes in-depth understanding because students are exposed to 'wrapped-around' and holistic learning, which enables them to compare and contrast concepts; relate these concepts to other subjects and experiences; and to generate questions and hypotheses that lead to further inquiry and new knowledge. Therefore, it is recommended that universities promote utilisation of the method and facilitate further research into its effectiveness.
\end{abstract}

Keywords: Curriculum innovation; Student-centred learning; MUBS

\section{$1 \quad$ Background}

Makerere university business school (MUBS) is the leading institution in Uganda in business training for both undergraduate and post graduate courses. Through innovative approaches, the school is engaging the private sector through entrepreneurship training programmes. It is also engaging an international student community through "hybrid" collaborations with universities in the United States. Though MUBS became a constituent school of Makerere university in 1998, it has since grown into a fully independent institution with a student population of up to ten thousand and offers a range of undergraduate and postgraduate courses, which are accredited by the Uganda National Council for Higher Education (NCHE).

The pedagogical approaches used in MUBS have remained traditional, majorly lecturer-led. Though the school has tried to be innovative, by training 
some staff in the case teaching method, these few staffs have not disseminated the knowledge to others. Interactions with some staff indicate that they lack skills in case design and analysis yet cases demand a lot of effort to research and could present challenging scenarios. On the other hand, students also seem to present a more ignorant position on the case method, with many indicating that cases tend to be long and demanding to read and generally requiring a lot of "out-of class" efforts.

Despite the advantages associated with the case method and MUBS' effort to promote its utilisation, therefore, there has not been any school-wide policy in this regard. Except in two courses (i.e. strategic management and marketing), there has been no effort by departments in general and lecturers in particular to integrate the use of cases in teaching. In fact, various departmental meetings have noted a general discomfort among many staff concerning the use of cases and, at one point in time, some lecturers abandoned teaching strategic management because the team leader insisted on use of cases.

It is against this background that this study examined performance in the courses using the case method, to demonstrate the efficacy of the method in the school's setting. The researcher hopes that this information could guide the school in its efforts to innovate its pedagogical approaches for improved learning.

\section{Related Literature, Knowledge Gap and Objectives}

\subsection{Case Teaching Method}

The case method is a form of learning where the students read a description of a (real) case or a problem taken from an existing area. The lecturer elaborates on what to do in this case by providing a range of guidelines, and then the students undertake a case analysis that enables them to make justifiable decisions to solve the problem. The case method emphasizes undertaking the analysis in groups. Indeed extant literature indicates no guide on group structure, dynamics or size, but the lecturer can innovatively form the groups depending on the total number of the students in the class. After that they meet with the class to present and discuss the case with one another and with the lecturers' facilitation.

The case method has been used at Harvard University and many other universities for more than 50 years, mostly within business and law studies. Business and law schools have had a long tradition of using real or simulated stories known as cases to teach students about their field (Christensen 1986), and valuable case books in the field have been written about the pedagogy ( $\mathrm{J}$. Erskine et al. 1981) indeed Robert Merry (1954) indicated that cases should 
improve students' learning through their joint, cooperative effort, rather than on the teacher conveying his/her views. Cases can be administered to students either in a discussion format, debate format, public hearing format, trial format, problem based learning format, and team learning format. Each of these formats has its own challenges and can be administered in combination depending on the situation.

For purposes of this research the author will concentrate on three formats namely; discussion, debate and team learning as these form the "hybrid" method used at MUBS, as these promote active learning (Myers \& Jones, 1993; Johnson, Johnson \& Smith, 1991), cooperative learning (Cooper 1991), and critical thinking (Paul, 1992).

\subsection{Student Engagement}

Extant literature shows that student engagement is increasingly seen as an indicator of successful classroom instruction, and as a valued outcome of school reform (Kenny et al 1995), and Schlecty (1994) contends that the phrase has been identified with, and widely used in education circles. Students are engaged when they are attracted to their work, persist despite challenges and obstacles, and take visible delight in accomplishing their work. Bomia, et al (1997), and this also focuses on student's willingness, need, desire and compulsion to participate in, and be successful in, the learning process, a view held by Chapman (2003) as depicting students' willingness to participate in routine school activities, such as attending class, submitting required work, and following teachers' directions in class. On the other hand, Fletcher (2005) indicates that the term is also increasingly used to describe meaningful student involvement throughout the learning environment, including students participating curriculum design, classroom management and school building climate.

Though many studies have focused on student engagement and have earmarked it a desirable trait in schools (Schlecty, 1994, Kenny et al 1995), there is little consensus among students and educators as to how to define it (Sharan et al, 1999). Though some studies link student engagement to student motivation, Williams (2003) has looked at student engagement in terms of both psychological and behavioural components, and that it focuses students' attitudes towards school, as opposed to student disengagement identifies withdrawing from school in any significant way.

Psychological engagement happens when a lesson captures students' imaginations, and attracts their meandering attention, indeed Strong et.al. (1995) indicates that this will lead to students give clear, immediate, and constructive feedback. Behavioural engagement reflects the student's actions within and outside the classroom environment, both as an individual or as a 
group (McCombs \& Pope, 1994; Fletcher, A. 2005). Chapman, E. (2003) contends that the term student engagement has been used students' willingness to participate in routine school activities, such as attending classes, submitting required work, and following teachers' directions in class. Skinner \& Belmont (1993) indicates that students who are engaged show sustained behavioural involvement in learning activities accompanied by a positive emotional tone. Whether psychological or behavioural, student engagement is indicated by; the level of academic challenge, collaborative learning, student-process interaction, enriching education experiences, initiative, self-motivation, independent experimentation, and peer coaching, and enthusiasm, indeed all the above will make students devote substantial time and effort to a task (Newman, 1986).

Despite being difficult to conceptualize, student engagement is recognized by teachers and researchers alike as an important link to student achievement and other learning outcomes (McGarity \& Butts, 1984; Capie \& Tobin, 1981).

\subsection{Student Involvement}

Extant literature indicates that student involvement is hinged on pedagogical practices and as a process it is based on multiple relationships and activities that enforce learning (Kember \& Gow, 1994; Astin, 1984) Astin's (1984) theory of involvement posits that students learn more the more they are involved in the academic aspects of the class experience. Students who are involved devote significant energy to academics, spend time discuss class/course works and interact often with one another. Importantly, the most persuasive types of involvement are academic involvement, that encourages class-peer interaction and is a lynch pin of student-centred teaching. According to Astin (1984), the quality and quantity of the student's involvement influences several educational outcomes including cognitive learning and academic performance, and for a student to be involved in the learning process, she or he must invest energy in academic relationships and activities. With student involvement there should be; student-lecturer contact, cooperation among students, active learning, prompt feedback, time on task, and expression of diverse talents.

Literature provides an interesting array of outcomes and supporting benchmarks for student involvement; Class-wide approaches - student-specific roles in building leadership, and; intentional programs designed to increase student efficacy as partners and equal players in classrooms (Fullan, 2000), Sustainable classroom structures of support - Policies and procedures are created and amended to promote meaningful student involvement within the

classroom. Sustainability within a class cannot be seen solely through a structural lens; instead, it must happen within a clear set of procedures (White \& Crump, 1993), Personal commitment - Students' dedication, relationships, and classroom culture builds a long term connection among students, Strong 
learning connections - Classroom learning and student involvement are connected by classroom credit, ensuring relevancy for educators and significance to students. Meaningful student involvement should not be an "add-on" strategy for lecturers but it should be integrated throughout their teaching activities (Cipolle, 2004).

\subsection{Student Performance}

Student performance can either be classroom based or assessment based. Though assessment-based student performance is undertaken through course works and examinations sat at the end of each course of study, and this has slightly been studied even though not in relation to case method of teaching, on the other hand, classroom-based student performance refers to the level of skill a student exhibits during and in a process of study in a classroom. Though assessment-based student performance can be measured directly using scores/ results of course works or examinations that can be computed in percentages, classroom-based student performance can be measured on the basis of skill development in terms of communicational, presentational, analytical and interpersonal abilities amassed by an individual student as a result of interaction with a particular process in classroom or largely in a learning process. This study will focus on classroom-based student performance since the case method of teaching is more of a process interaction between students and lecturers than assessment-based student performance which based on only the lecturers assessment of students work. And according to William Daggart of the International Centre of Leadership in Education student performance is a base of skills such as problem solving, decision making, innovation, creativity, respect, responsibility, organizational skills, initiative, and perseverance. They can be developed as much by how we teach as by what we teach and these skills have a great deal to do with instruction, not just content.

\subsection{Knowledge Gap}

Little is known or evidenced in the school's efforts to track student performance apart from the summaries made on the results sheet (Course files 2007, 2008), and indeed no apparent analysis of any kind has been done in respect students interaction in and with the process of study and how this would affect their performance. Despite the importance of cases and case method of teaching in enhancing student performance, there has been a lukewarm reception among many circles within university lecturers and students in the few universities in the developing world that have embraced this method (Chapman, 2003), indeed MUBS is no exception to this. There has been widespread misconception and ill feeling about the case method of teaching 
(MUBS Course files 2006, 2007, 2008), and this is exemplified by the failure to adopt the case method by many courses except strategic management and marketing case study, despite the school wide encouragement. An analysis of all academic based policies indicates no known efforts prior to this study specifically at MUBS that have a focal attention on student engagement and involvement and their influence on student performance.

\subsection{Objectives and Conceptual Framework}

The major purpose of the study is to examine the relationship between the case method of teaching and student performance in a university setting. The specific objectives were to establish the relationship between the case method of teaching and student engagement, involvement and performance. The variables involved in the study were conceptualized as delineated in Figure 1.

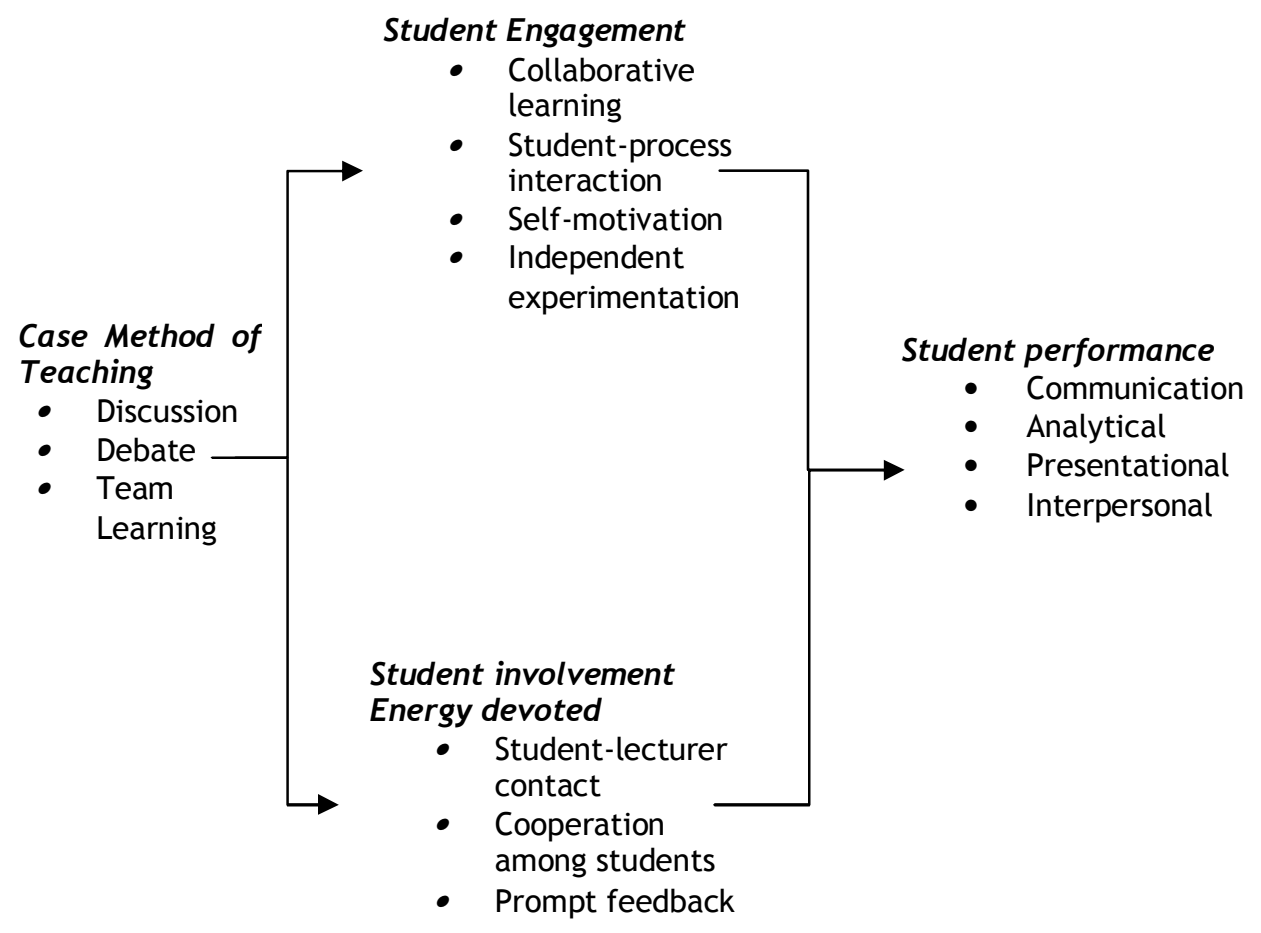

Figure 1: Case Teaching Method and Students' Performance

Source: Adapted from Erskine et al. (1981); Newman (1986); Astin (1984) 


\section{$3 \quad$ Methodology}

\subsection{Population and Sample}

Data were collected on the performance of Bachelor of Leisure and Hospitality Management students offering strategic management (Semester Two of the 2007/2008 academic year). The population consisted of 111 students. The researcher used the class list provided by the faculty as a complete sampling frame from whom a sample of 80 respondents was selected using simple random sampling. The size of the sample was determined from Morgan and Krejcie (1970)'s sample size estimation table cited by Sekaran (2004, p.294).

\subsection{Data Collection Procedures}

Data were gathered from University Students in a University. Primary data was collected through the use of self-administered questionnaires, and the researcher distributed and collected the questionnaires from the students, of the 80 questionnaires sent out, the researcher managed collect back 51 questionnaires amounting to $63.75 \%$ response rate. The self-administered questionnaire approach was preferred because this made data collection easy and manageable. To establish reliability and validity, the questionnaire was pretested on 10 respondents, an equivalent of $10 \%$ of the sample size (Saunders et al, 2003) and the test results are indicated later. The first part of the questionnaire consists of the general information of the respondent, Case Method of Teaching attributes were used in the second part, which is the independent variable of this research. The third part of the questionnaire explains Student Engagement and Student Involvement, and these are the independent/dependent variable of this research. The final part consists of Student Performance and this is the dependent variable of this research. The Introduction part of the questionnaire was designed to provide explanation for each part to the respondents.

\subsection{Validity and Reliability}

The data collected were valid because the items in the data collection instrument were culled from literature related to the variables studied while others were adapted from instruments used in related studies (i.e. concomitant validity). The internal consistency method was used to ascertain the reliability of the study because the study uses multiple items in all constructs. Hair et al. (2007) mentioned that the rationale for internal consistency is that the individual items or indicators of the scale should all be measuring the same 
construct and thus be highly inter-correlated and as it is the items in this study are (Table 1).

Table 1: Reliability Coefficients

\begin{tabular}{lcc}
\hline Variable/Combined items & Anchor & Cronbach's a \\
\hline Case Method of Teaching & 5 & 0.80 \\
Student engagement & 5 & 0.88 \\
Student Involvement & 5 & 0.805 \\
Student Performance & 5 & 0.84 \\
\hline
\end{tabular}

\section{$4 \quad$ Results and Discussion}

\subsection{Age Group by Gender Distribution of the respondents}

Table 2 shows the distribution of respondents by age and gender.

Table 2: Distribution of Respondents by Age and Gender

\begin{tabular}{|c|c|c|c|c|c|}
\hline & & & & nder & \\
\hline & & & Male & Females & lotal \\
\hline & & Count & 17 & 20 & 37 \\
\hline & Below 30 & Row \% & 45.9 & 54.1 & 100 \\
\hline & & Column \% & 73.9 & 71.4 & 72.5 \\
\hline & & Count & 6 & 6 & 12 \\
\hline Age Group & $31-40$ & Row \% & 50.0 & 50.0 & 100 \\
\hline & & Column \% & 26.1 & 21.4 & 23.5 \\
\hline & & Count & & 2 & 2 \\
\hline & $41-50$ & Row \% & & 100.0 & 100 \\
\hline & & Column \% & & 7.1 & 3.9 \\
\hline & & Count & 23 & 28 & 51 \\
\hline Total & & Row \% & 45.1 & 54.9 & 100.0 \\
\hline & & Column \% & 100 & 100.0 & 100.0 \\
\hline
\end{tabular}

The female students dominated the sample (54.9\%) while their male counterparts comprised only $45.1 \%$ of the sample. Among the Females, the majority were below 30 years $(71.4 \%), 21.4 \%$ of them were in the $31-40$ year age group and the other $7.1 \%$ were in the 41.50 year age group. On the other hand, the males were dominantly of the "Below 30 year age group" $(73.9 \%$.) It was observed that there were no males students in the 41-50 year age group but all respondents in this age group were the females. The results were also presented using the figure below. 


\subsection{Gender and Preferred Method of Teaching}

Table 3 shows the distribution of respondents by most preferred method of teaching.

Table 3: Distribution of Respondents by Preferred Method of Teaching

\begin{tabular}{lllllll}
\hline & & \multicolumn{3}{c}{ Most Preferred Method of Teaching } & \multirow{2}{*}{ Total } \\
\cline { 3 - 6 } & & & Case study & Straight Lectures & Others & \\
\hline \multirow{4}{*}{ Gender } & \multirow{3}{*}{ Male } & Count & 9 & 13 & 1 & 23 \\
& & $\%$ & 39.2 & 56.5 & 4.3 & 100 \\
& \multirow{4}{*}{ Female } & Count & 11 & 16 & 1 & 28 \\
& & $\%$ & 39.3 & 57.2 & 3.5 & 100 \\
\multirow{2}{*}{ Total } & & Count & 20 & 29 & 2 & 51 \\
& & $\%$ & 39.2 & 56.9 & 3.9 & 100 \\
\hline
\end{tabular}

Table 3 shows that majority $(56.9 \%$,) of the respondents prefer straight lectures while those who preferred Case Study comprised $39.2 \%$ of the sample and those who prefer other methods were in the minority $(3.9 \%)$. Interesting to note is the consistence across gender in the results with both males $(39.2 \%)$ and females $(39.3 \%)$ preferring the case method of teaching and also $56.5 \%$ and $57.2 \%$ respectively between the genders for straight lectures, this would indicate that there might not be any significant differences as a result of gender disparity.

\subsection{Case Method and Student Engagement, Involvement and Performance}

The zero order correlations were employed to explore the relationships between, on one hand, the case method and, on the other hand, students' engagement, involvement and performance. The results are summarized in Table 4.

Table 4: Case Method and Student Engagement, Involvement and Performance

\begin{tabular}{lcccc}
\hline & 1 & 2 & 3 & 4 \\
\hline Student Engagement-1 & 1.000 & & & \\
Student Involvement-2 & $.688^{* *}$ & 1.000 & & \\
Case Method of Teaching-3 & $.514^{* *}$ & $.531^{* *}$ & 1.000 & \\
Student Performance-4 & $.736^{* *}$ & $.604^{* *}$ & $.749^{* *}$ & 1.000 \\
\hline
\end{tabular}

** Correlation is significant at the 0.01 level (2-tailed). 


\subsection{Relationship between Case Method and Students' Performance}

The results in the table above showed that the Case method of teaching and student performance are significantly and positively related $\left(\mathrm{r}=.749^{* *}, \mathrm{p}<.01\right)$. In addition, student Engagement $\left(\mathrm{r}=.736^{* *}, \mathrm{p}<.01\right)$, Student Involvement( $\mathrm{r}$ $\left.=.604^{*} *, \mathrm{p}<.01\right)$ were also positively related to Student performance. The results imply that the better the management of administering course content using the Case method of teaching, the better the levels of student performance that will be observed. The findings indicate a positive relationship, and indeed as contended by Erskine et al. (1981) cases do improve student learning through flexible pedagogical approaches that are involving and problemsolving based. All the dynamics students go through to prepare, discuss, debate and present case findings or solutions are significant activities that have not only psychological and behavioural impact, but also both short-term and longterm capability development among the students, and these will in-turn improve student performance

\subsection{Relationship between Case Method and Students' Student Involvement}

The results also showed that the Case method of teaching and Student Involvement were positively related $\left(\mathrm{r}=.531^{* *}, \mathrm{p}<.01\right)$. These results show that the Case Method of Teaching enhances the level of Student Involvement. The Student Involvement was also observed to have a positive relationship with Student Performance $\left(\mathrm{r}=.604^{* *}, \mathrm{p}<.01\right)$. Case Method of teaching therefore enhances the level of student Involvement which in turn also leads to improved levels of student performance. The findings above indicate a rather positive relationship between the case method of teaching and student involvement, this establishment is an outcome of good classroom culture, student commitment, and strong student-learning based relationships especially as advanced by (Kember \& Gow, 1994).

\subsection{Relationship between Case Method and Students' Engagement}

The Case Method of Teaching and Student Engagement were also observed to be significantly and positively related $\left(\mathrm{r}=.514^{* *}, \mathrm{p}<.01\right)$. Furthermore, the level of Student Engagement was observed to be related to the level of Student Engagement $(\mathrm{r}=.736, \mathrm{p}<.01)$. The results also highlight the potential of the Case Method of teaching to enhance the level of student engagement which in turn results into improved Student Performance. Whereas Strong et.al (1995) emphasizes that capturing student's imagination increases Psychological engagement, and McCombs \& Pope (1994) contends that student's actions within classrooms reflect behavioural engagement, these are paramount 
indications towards student performance. Indeed the findings have revealed that there was such a positive relation between the case method of teaching and student engagement $\left(\mathrm{r}=.514^{* *}, \mathrm{p}<.01\right)$. This indicates a big potential of the Case Method of teaching towards enhancing student engagement and performance $(\mathrm{r}=.736, \mathrm{p}<.01)$. These findings supplement further the arguments that student engagement is based on a successful classroom instruction (Kenny et al 1995).

\subsection{Prediction Model}

These results highlight the extent to which the predictors i.e. Student Engagement, Case Method of Teaching and Student Involvement can explain the level of Student Performance (Table 5).

Table 5: Prediction Model

\begin{tabular}{|c|c|c|c|c|c|c|c|}
\hline \multirow[t]{2}{*}{ Model } & \multicolumn{2}{|c|}{$\begin{array}{l}\text { Unstandardized } \\
\text { Coefficients }\end{array}$} & \multirow{2}{*}{$\begin{array}{c}\text { Standardized } \\
\text { Coefficients } \\
\text { Beta }\end{array}$} & \multirow{2}{*}{$\mathrm{t}$} & \multirow{2}{*}{ Sig. } & \multirow{2}{*}{\multicolumn{2}{|c|}{$\begin{array}{l}\text { Dependent Variable: } \\
\text { Student Performance }\end{array}$}} \\
\hline & B & $\begin{array}{l}\text { Std. } \\
\text { Error }\end{array}$ & & & & & \\
\hline (Constant) & .549 & .340 & & 1.613 & .114 & R Square & .729 \\
\hline Engagement & .486 & .113 & .468 & 4.290 & .000 & Adjusted R Square & .711 \\
\hline Case Method & .369 & .069 & .499 & 5.340 & .000 & F Change & 41.18 \\
\hline Involvement & .018 & .108 & .018 & .164 & .871 & Sig. F Change & .000 \\
\hline
\end{tabular}

These results highlight that the predictors can explain up to $71.1 \%$ of the variance in the Student Performance (Adjusted R Square $=.711$ ). These results further reveal that the Case Method of Teaching was the most powerful at explaining the Student Performance $($ Beta $=.499$, sig. $=.000)$ and this was closely followed by the Student Engagement $($ Beta $=.468$, Sig. $=.468$, Sig. $=$ .000 ). Overall, the regression model was significant (sig. F Change $=.000$ ). Indeed the ability of the case method of teaching to predict up $71.1 \%$ of student performance indicates the student's ability to communicate, analyze, and meaningfully present ideas, as well improved interpersonal-relationships are key components, and all these skills developed for a student will improve the level of performance.

\section{$5 \quad$ Conclusion and Implications}

From the above discussions it is clear that though the case method of teaching is not the most preferred (45.1\%), and as indicated earlier in the background that in the universities that are innovatively implementing it there is a lukewarm reception, there significant indications that it is the most effective method in enhancing student performance especially with the prediction potential of 71.1 
$\%$. Since student performance reflects much on the skills that emerge from the instruction mode rather than the content as discussed in the literature, adopting this method and effectively implementing in Universities would generally increase student performance and thus out graduates with relevant skills to the job market. This is further supported by the fact that the relationship between the case method of teaching and student engagement and involvement are significant, and they also influence student performance. It is therefore it implies that Universities should establish clear policies that emphasize the use of case method of teaching in their pedagogical approaches as these will enhance student performance.

Also Universities should train their staff in the case method of teaching to help them gain the necessary pedagogical skills needed, perhaps this would increase the case "reception" levels among the academic staff. As the trainers and facilitators should be the first among those to appreciate this method and thus Universities should integrate in their human resources development plan, components to do with training staff in the case method with specific focus on case writing and design, case analysis, developing the case assessment tools and most importantly using cases as a method of teaching.

The other implication is that Universities should facilitate case-focused research both among the staff and students in order to gain new insights and also undertake benchmarking study visits to Universities that are known to use the case method of teaching perfectly. Though this study was based on the a single course and this would have been methodologically limiting, efforts in future research may be put on broadening the population to include all courses that use the case method, study the relationships between the case method of teaching and exam performance and grades, and longitudinal research may suffice here and also include the academic staff, these and other research efforts may be undertaken to further strengthen the call.

\section{References}

Astin, A. W. (1984). Student involvement: A developmental theory for higher education. Journal of College Student Personnel, 25, 297-808.

Bomia, L., Beluzo, L., Demeester, D., Elander, K., Johnson, M., \& Sheldon, B. (1997). "The impact of teaching strategies on intrinsic motivation." Champaign, IL: ERIC Clearinghouse on Elementary and Early Childhood Education. p. 294

Capie, W. \& Tobin, K. (1981). Pupil engagement in learning tasks: A fertile area for research in science teaching. Journal of Research in Science Teaching, 18(5), 409-417.

Cipolle, Susan (2004) "Service-learning as a counter-hegemonic practice: Evidence pro and con," Multicultural Education, 11(3), 12-23. 
Chapman, E. (2003) "Assessing student engagement rates," ERIC Clearinghouse on Assessment and Evaluation. ERIC identifier: ED482269.

Erskine, James A., Michiel R. Leenders, and Louis A. Mauffette-Leenders. 1981. Teaching with Cases. Waterloo, Canada: Davis and Henderson Ltd.

Fullan, M. (2000). "The three stories of education reform," Phi Delta Kappan, $81(8), 581-584$.

Hair, J.; Black, W.; Babin, B.; Anderson, R.; and Tatham, R. (2007)Multivariate Data Analysis. 6th Ed. New Jersey: Pearson Education, Inc.

Kember, D., \& Gow, L. (1994). Orientations to teaching and their effect on the quality of student learning. Journal of Higher Education, 65, 58-74.

Kenny, G. Kenny, D. and Dumont, R. (1995) Mission and Place: Strengthening Learning and community through campus design. Oryx/Greenwood. p. 37

Fletcher, A. (2005) Guide to Students as Partners in School Change. Olympia, WA: SoundOut.

McCombs, B. L., \& Pope, J. E. (1994). "Motivating hard to reach students." Washington, DC: American Psychological Association.

McGarity, J. \& Butts, D. (1984). The relationship among teacher classroom management behaviour, student engagement, and student achievement of middle and high school science students of varying aptitude. Journal of Research in Science Teaching, 21(1), 55-61.

Merry, R. W. 1954. Preparation to teach a case. In The Case Method at the Harvard Business School. (Ed.) McNair, M. P. with A. C. Hersum. New York: McGraw-Hill.

Newman, F. (1986). Priorities for the future: Toward a common agenda. Social Education, 50(4), 240-250.

Sharan, S. S., H. and Levine, T. (1999) The Innovative School: organization and instruction. Praeger/ Greenwood. p. 85.

Schlecty, P. (1994). "Increasing Student Engagement." Missouri Leadership Academy. p.5.

Skinner, E. A., \& Belmont, M. J. (1993). "Motivation in the classroom: Reciprocal effects of teacher behaviour and student engagement across the school year." Journal of Educational Psychology, 85(4). p. 572.

Strong, R. Silver, H. and Robinson, A. (1995) "What do students want (and what really motivates them)?" Educational Leadership. September. p. 25.

Williams, J. D. (2003) Student Engagement at School: a sense of belonging and participation: Results from PISA 2000. Organization for Economic Cooperation and Development.

White, C. and Crump, S. (1993) "Education and the three 'P's: Policy, politics and practice: A review of the work of S. J. Ball," British Journal of Sociology of Education, 14(4) pp. 415-429 useful for understanding the role of policy in creating sustainable conditions in schools. 